\title{
Predicting Audit Opinions Evidence From The Athens Stock Exchange
}

Anastasia Maggina, Business Consultant/Researcher, Greece Angelos A. Tsaklanganos, University of Nicosia, Cyprus

\begin{abstract}
The purpose of this study is to provide evidence drawn from publicly traded companies in Greece as far as the predictability of going-concern opinions, and other business situations (problem companies, tax contingent liabilities) based on a transition from a tax-driven accounting system which is characterized by a stakeholder (debtholder) orientation to shareholder oriented and independent of tax reporting considerations after the adoption of IFRS. This study examines companies listed in the Athens Stock Exchange to determine whether the findings with regard to the prediction of troubled companies, going-concern audit opinions and tax contingent liabilities are robust in a different accounting system than that in prior studies. We employ discriminant analysis and a logit specification to test our models. Results indicate that more noticeably goingconcern audit opinions can be predicted with rates ranging from $96.7 \%$ to $98.7 \%$.

Research findings are subject to limitations since they are drawn from publicly traded companies only. The selection of models that better fits to the Greek data provides additional evidence to the existing literature not only in so far as the statistical techniques but also in respect to the business environment (after the adoption of IFRS). These models can act as early warning systems in an effort to avoid further bankruptcies or liquidations or even to prevent "window dressing" phenomena.
\end{abstract}

Keywords: audit reports; going-concern opinions; problem companies; tax contingent liabilities; discriminant analysis; logit specification; prediction

\section{INTRODUCTION}

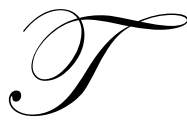

he appointment of auditors was optional since 1872 in Greece and became mandatory in 1955(Legislative Decree 3329/1955) when the Board of Sworn-in Auditors was established. According to Company Law 2190/1920 (Article 108) as revised by Company Law 3604/2007 (Article 42A), companies which are subject to the audit by independent auditors are all corporations and limited liability companies that fulfill any two of the following three criteria: 1) total assets at least 2.5 million euro, 2) annual turnover at least 5 million euro, and 3) average of at least fifty persons employed during the financial year.

The traditional excerpt of an unqualified audit opinion reads: "In our opinion, the accompanying individual and consolidated financial statements present fairly, in all material respects, the financial position of the Company and of the Group as of December 31, 2007 and of its financial performance and its cash flows for the year then ended in accordance with the International Financial Reporting Standards (IFRS) as adopted by the European Union."

In about half of the cases of audit reports there are notes with the most frequent the following statement. Without qualifying our opinion, we draw attention to:

Note 5 in the Notes on the financial statements, where reference is made to the fact that the tax returns of the Company, for the respective years, have not been examined by the tax authorities as yet and, as a consequence, the possibility exists of additional taxes and penalties being assessed at the time when the returns will be examined and 
will be accepted as final. The outcome of these tax inspections cannot be predicted at present and, no provision has been made in these financial statements in this respect."

Qualified audit reports are usually issued for: scope limitations, violation of GAAP, material misstatements, inadequate disclosure, change in accounting method not justified, etc. There are also "modified" audit reports that warn users of particular issues. Strictly speaking these are unqualified reports, since no misstatements are detected. Modified audit reports are usually issued for: change in accounting method justified, going-concern, divided responsibility report (more than one auditor), justified departure from GAAP, emphasis on a specific matter. Auditors use this report(s) to draw attention to an important accounting issue or an audit scope/test issue.

A pending tax problem seems like it is a disclosure issue (a contingent liability that is not probable and measurable so no official recording is necessary but disclosure is necessary). If the statement discloses this, the audit report need not be altered. However, if it is material, this could be an emphasis of a matter. In Greece, the audit reports are classified as unqualified reports, matters of emphasis, with exception, negative opinion, and qualified opinion.

According to Spathis (2003) most of qualifications in financial statements in Greece were of the "except for" type of qualification that is given when the matter is a material but not fundamental uncertainty or disagreement.

In the literature two types of qualified opinions are issued more frequently: consistency qualifications and contingency or "subject to" qualifications. Normal business operations involve many contingencies such as pending lawsuits, disputes with regulatory bodies, recoverability of asset costs, (possible)violations of debt covenants, and tax status of certain transactions. companies:

The motivation of this study is focused on the following determinant factors with regard to Greek listed

1. the very low rate of qualified audit reports $(0.69 \%)$ in the year 2007 which reduced to $0.00 \%$ in 2008 . It was also $0.00 \%$ in 1998,2005 and 2004 ,

2. the change of strictly unqualified reports from $58.04 \%$ in 2007 to $81.36 \%$ in 2008 . It was 27.53 in $1998,36.42 \%$ in 2005 and $8.4 \%$ in 2004$)^{\mathrm{i}}$,

3. the very high rate of tax contingent liabilities $(35.31 \%)$ in the year 2007 which reduced to $6.45 \%$ in 2008 . It was $7.62 \%$ in $1998,47.60 \%$ in 2005 and $49.86 \%$ in 2004 ,

4. the increase of the rate of "going-concern opinions" from $2.79 \%$ in 2007 to $5.36 \%$ in 2008 . It was $3.19 \%$ in 2005 and no going-concern opinions in 2004,

5. audit reports with notes about accounting method changes represent $82.63 \%$ in $2004,30.67 \%$ in $2005,5.09 \%$ in $2007,5.73 \%$ in 2008 and $69.92 \%$ in 1998 ,

6. the lack of disclosure of audit and other non-audit fees by Greek firms,

7. the fact that only one out of every two executives of Greek listed companies has a theoretical knowledge of IFRS which implies that auditing firms have been involved at least in training programs to Greek listed companies in the transition period to IFRS. of IFRS, etc.

Note that 2005 is the first year after the adoption of IFRS in Greece, 2004 is one year before the adoption

This study is justified in a different context than other studies. It is justified in the framework of IFRS and, in particular, three years after their adoption. IFRS were effective since 2005 and the date of audit opinions are dated in 2007.The contribution of this study is that it provides evidence from the Athens Stock Exchange (ASE) listed companies based on a tax-driven accounting system which is characterized by a stakeholder (debtholder) orientation which stands in a transition to shareholder oriented and independent of tax reporting considerations after the adoption of IFRS. Note that the debt to equity ratio of ASE listed companies in a time horizon of four and a half decades stands on average to 1.24 (minimum) in 2004 and 3.068 (maximum) in 1984 (with outliers excluded). 
The rest of the paper is organized as follows: Section 2 discusses the review of the literature. Section 3 describes the research design. Section 4 presents the empirical analysis and results. Section 5 concludes with suggestions for further future research.

\section{REVIEW OF THE LITERATURE}

Audit reports supplement the accounting information drawn from the financial statements. They provide a means of increasing the credibility of management disclosures. Thus the combination of audit reports and financial statements data can be a good predictor of several business events. The main part of the literature turns around the cause and effect relationship between audit qualification and bankruptcy prediction. A series of studies examined the relationship between a going-concern audit opinion and bankruptcy and the findings indicate approximately $40 \%-$ $48 \%$ received "going concern" qualifications one-year prior to bankruptcy. These studies have examined different time periods.

Altman and McGough (1974) found that $46.4 \%$ of their sample of bankrupt companies had received the "going-concern opinion" one year prior to the bankruptcy event. McKee's research (1976) constructed an objective model based on financial ratios to help auditors in making going-concern judgments. He is one of the first researchers who suggested discriminant prediction of "going-concern" status, who reported an overall accuracy rate of $87.18 \%$.Deakin (1977) extended the analysis to cases two years prior to the bankruptcy event and found that $14.9 \%$ of the bankrupt companies had received the "going-concern" opinion. Alternative studies constructed models to assist the auditor in making going-concern judgments.

Building on McKee's work, Kida (1980) investigated various aspects of auditors' going-concern judgments and qualification decisions given financial statement data. A subset consisting of 5 ratios was selected which accurately distinguished problem (troubled) from non-problem firms, representing various characteristics familiar to auditors. He has suggested that non-qualification may also be due to the perceived consequences of qualification and not only the inability to detect "going-concern" problems. Altman (1982) found that $48.1 \%$ of his companies that went bankrupt during 1972-1982 had received the "going-concern" qualification one year prior to bankruptcy. Dodd et al. (1984) and Elliott (1982) all found that companies receiving qualified opinions report later than companies receiving unqualified opinions. As expected, companies that receive going-concern opinions have a longer audit delay than companies that do not receive the qualification. This is due to the fact that auditors may be required to spend more time on troubled companies.

Several studies examined qualitative as well as quantitative variables to study the relationship between bankruptcy and the "going-concern" opinion. Mutchler (1985) investigated the extent to which the "going-concern" opinion could be predicted using only publicly available information (both quantitative and qualitative). She concluded that qualitative variables that included good and bad news items had no incremental explanatory power relative to financial variables in a model of the auditor's opinion decision for financially distressed companies. The model with the ratios and prior year opinion variable had the highest overall predictive accuracy (approximately 83\%). Mutchler (1986) focused on a set of manufacturing companies to identify potential "going-concern" opinion recipients and to identify factors related to the final opinion decision based on 6 financial ratios with similar results to her 1985 study. In a later study, Menon and Schwartz (1986) found that 43\% of their companies that had entered bankruptcy during the 1974-1983 period after receiving a "going-concern" qualification one year prior to bankruptcy.

Dopuch, Holthausen and Leftwich (1987) present a predictive model of audit opinion qualifications in which the variables with the greatest predictive power were a categorical variable indicating whether the firm recorded a loss during the year being audited and the firm's change in residual standard deviation of returns. They investigated the extent to which models based on 5 financial and market variables predict whether an auditor will issue a first-time qualified opinion in the current year, or another qualified opinion in the subsequent year. The results showed that the most significant variables in qualification prediction are current year loss, industry return (percent) and the change in the ratio of total liabilities to total assets. Of three qualification types, the going-concern opinion had the highest accuracy rate in prediction. Their results indicate that the probability of a first-time "subjectto" opinion is negatively correlated with accounting losses for the audit year. 
Keasey and Watson (1987) showed that marginally better predictions of small company failure may be obtained from non-financial audit information (prior years' qualification, current year qualification) than from using traditional financial ratios. Delays in reporting for firms with audit qualifications were studied by Ashton et al. (1987).They conclude that audit qualifications explain delays in reporting.

Keasey et al. (1988) used the logistic analysis based on 20 financial and non-financial variables to explain qualification in small companies. Their results showed that the likelihood of receiving a qualified audit report was significantly greater if the company had been audited by a large firm of accountants, had few directors, few nondirector shareholders, a secured loan, and if there was a long lag between the auditing year-end and the signing of audited accounts. Hopewood et al. (1989) investigated the usefulness of the audit opinion (consistency exception, i.e. "subject to" opinion and going concern opinion) in providing incremental explanatory power for bankruptcy. The purpose of their study was to explore the question of the ability of qualified opinions to serve as warning signals for bankruptcy. Their log-linear approach based on 5 financial ratios showed that the consistency exception and going concern opinion had incremental explanatory power beyond financial ratios in bankruptcy prediction models. They showed that a qualified opinion was a good predictor of failure. Bankrupt companies were significantly more likely to receive a qualified opinion of any type in the year immediately preceding bankruptcy. The results of the research provided credence to financial statement users' insistence that the qualified opinion had the ability to serve as an early warning signal for entity failure.

Koh and Killough (1990) constructed a failure prediction model using step-wise MDA based on 21 financial ratios and demonstrated its use in making going-concern judgments. They have shown that the model can detect going-concern problems with an overall accuracy rate of $88.25 \%$ which is slightly greater than the auditors' accuracy rate of $86.50 \%$. Koh (1991) compared the predictions of a probit bankruptcy prediction model based on 6 financial ratios and the assessment of auditors on the going-concern status. The model outperformed auditors in making going-concern assessments and can thus be useful to auditors in assessments. McKeown et al. (1991) developed and tested formal models that explain, at least in part, why auditors often fail to qualify the opinions of companies that go bankrupt. Their model incorporates financial stress, auditor factors, and client factors, and in terms of these variables, it explains the differences between those bankrupt companies that receive the goingconcern qualification and those bankrupt companies that do not receive the going-concern qualification. Since only bankrupt companies are considered, the model explains why auditors qualify the opinions of some bankrupt companies and not others.

Bell and Tabor (1991) developed an audit decision aid to predict uncertainty reporting decisions with the final model containing six measures representing 5 financial factors. Their model predicts a significantly higher average probability of qualification for the more serious multiple uncertainty qualification (including going-concern qualifications) compared to the less serious specific (asset realization) uncertainty qualification.

Chen and Church (1992) incorporated default status, a company defaulting on debt, as an additional indicator and investigated the usefulness of default status in identifying firms receiving a going-concern opinion. They also investigated the usefulness of default status in explaining the weak association, found previously, between the issuance of going-concern opinions and the occurrence of bankruptcies. A going-concern model was constructed based on 4 financial variables that have been used previously. They found while financial variables were important, default status is also a significant variable that can explain the auditor's choice. They found that adding a default status variable to an opinion decision model containing only financial variables, increased the predictive accuracy of their model from $38 \%$ to $93 \%$, thus indicating the importance of this variable. Their findings clearly indicate that firms in default or in the process of restructuring debt are more likely to receive a going-concern opinion than other firms.

Choi and Jeter (1992) hypothesize that a qualified audit opinion (consistency qualifications and contingency, or "subject to" qualifications) reduces the market's responsiveness to earnings announcements of the firm subsequent to the period of qualification. Ten indicators that could reveal changes in the economic/information environment and proxies of these variables that affect earnings response coefficients (ERC)** have been employed. (ERC has been shown to be inversely related to the market's expectation about the amount of uncertainty, or noise, in the firm's present and future earnings numbers and positively related to earnings persistence). Their results are 
consistent with the hypothesis that ERCs are altered subsequent to the issuance of a qualified audit opinion. For both consistency qualifications stemming from discretionary changes in accounting principles and "subject to" qualifications (without mentioning the going-concern violation), the post-qualification ERC declined significantly.

Louder et al. (1992) using a standardized cumulative abnormal returns model with market expectation, unexpected earnings and lateness as independent variables showed that when the market is not expecting a qualified opinion, there is a negative reaction on the qualification announcement date, and when the market is expecting a qualification and it is not announced at the earnings announcement date, there is a negative effect on security returns at the earnings announcement date. Goodman et al. (1995) found that particular combinations of specific nonfinancial data could accurately discriminate between those firms receiving and those not receiving going-concern modifications to the audit report. Sundgren (1998) has shown that audit reports include only marginal additional information over financial ratios in bankruptcy prediction. He studied 315 non-failing Finnish firms and found that in $91 \%$ the audit report followed the standard form. The same percentage among 127 failing companies was as low as $53 \%$. Their results show that non-professional auditors are less likely to qualify the report but there are no significant differences between the other types of auditors.

Mutchler et al. (1997) developed a list of 82 potential good news items, and found different results in an extension of the 1985 study. They studied how qualitative information released in the Wall Street Journal Index, specifically payment defaults and debt covenant violations, affected the probability of a company receiving a "going-concern modified report". All the companies in their sample were in the category of "soon to be entering bankruptcy". They found that the bad news items of payment default and debt covenant violation were significantly associated with issuance of the "going-concern modified report" by the auditor. They also found that the probability of bankruptcy was also significantly associated with the "going-concern" report.

Laitinen et al. (1998) showed that the qualification of an audit report is mainly associated with poor profitability, high indebtedness and low growth. The qualification decision was explained by 16 financial ratios and by the audit lag. The logistic model showed that the likelihood of receiving a qualification by large Finnish companies is larger, the lower the growth of the firm, the lower the share of equity in the balance-sheet and the smaller the number of employees.

Bartov et al. (2001) assert that auditors may be more likely to issue qualified reports for firms with extreme earnings, perhaps to mitigate litigation risk. Their analysis followed because "Big Six auditors" are identified in the literature as higher quality auditors due to their technological capacity of detecting earnings management, and once detected, a higher probability of reporting it.

Spathis (2003) developed a model based on financial information and other indicators such as firm litigation, to explain qualifications in audit reports of Greek companies. His results clearly indicate that firm litigation, financial distress and current year losses are the major indicators of audit qualification opinion. Models are accurate in classifying the total sample of 50 qualifications and 50 without qualifications correctly with accuracy rates of approximately 78\% and 75\% (logistic and OLS models). Caramanis and Spathis (2006) using a sample of 185 Greek companies listed at the Athens Stock Exchange and analyzed with a logistic and OLS regression models tested the extent to which combinations of financial information with non-financial variables, such as audit fees and type of audit firm, can be used as predictors of audit qualifications. On the contrary, good predictors are some financial variables (Operating Income/Total Assets and, current ratio).

Gaganis et al. (2007) proposed the application of probabilistic neural networks (PNNs) that combine the computational power and flexibility of artificial neural networks (ANNs) in a sample of 264 financial statements that received a qualified audit opinion over the period 1997-2004 and 3069 unqualified ones from 881 firms listed on the London Stock Exchange using a set of variables that consist of absolute measures, financial ratios and nonfinancial information. Their results indicate the high explanatory power of the PNN model in explaining qualifications in audit reports. Martens et al. (2008) using more advanced data mining techniques such as support vector machines and rule-based classifiers, they empirically investigated sampling methodology issues. They infer rules with the state-of-the-art classification technique AntMiner ${ }^{+}$, which are subsequently converted into a decision table allowing for truly easy and user-friendly consultation in every day audit business practices. 


\section{RESEARCH DESIGN}

Prior studies have employed a variety of methodologies. This study examines companies listed in the Athens Stock Exchange to determine whether the findings in other countries are robust when Greek listed companies are examined.

\section{Sample Selection And Data Used}

Companies listed in the Athens Stock Exchange (ASE) have been selected for investigation in this study. The size of the sample is based on the number of firms appeared in the Internet in the year 2007, that is three years after the adoption of IFRS.

The total number of firms included in the final sample is 286 companies that have announced audit reports in the year 2007.Eleven companies have been deleted because they do not present a series of financial statements for two consecutive years before the announcement of the audit report. Thus far, 275 companies are included in the final sample. As it has been mentioned only two companies exhibit a qualification $(0.72 \%)$, that is, one company has a strictly qualified report and the second has a going concern opinion that has been classified as a qualified opinion. Companies with tax contingent liabilities represent $35.27 \%$, companies with going-concern opinions represent $3.27 \%$, companies with change in accounting methods represent $5.09 \%$, companies with legal disputes represent $1.45 \%$, among other notes (i.e. debt restructuring, overdue debt, etc.).

\section{Research Method Used}

Discriminant analysis and logit models have been employed in this study. Discriminant analysis and logit were performed with type of opinion as the dependent variable and eleven financial ratios as independent variables.

Discriminant analysis is a statistical technique used for predicting group membership on the basis of the values on a set of predictors' variables. It operates with the conditional distribution of $\mathrm{x}$ (explanatory variables) given y (dependent variable). The model has the following general form:

$\mathrm{Y}_{\mathrm{i}}=1$ if $\mathrm{P}\left(\mathrm{Y}_{\mathrm{i}}=0 / \mathrm{X}_{\mathrm{i}}^{*}\right) \mathrm{L}_{01}<\mathrm{P}\left(\mathrm{Y}_{\mathrm{i}}=1 / \mathrm{X}_{\mathrm{i}}^{*}\right) \mathrm{L}_{01}$

$\mathrm{Y}_{\mathrm{i}}=0$ otherwise

Where

$\mathrm{P}\left(\mathrm{Y}_{\mathrm{i}}=1 / \mathrm{X}_{\mathrm{i}}^{*}\right)$ as a posterior probability of $\mathrm{Y}_{\mathrm{i}}=1$.

A logit model specifies the conditional distribution of $y$ given $x$. It assumes that $g(x)=\operatorname{logit}\{P(x)\}$ is the linear function of covariates $(\mathrm{x})$ of the $\mathrm{i}^{\text {th }}$ subject with the logit as the dependent variable. Specifically,

$\mathrm{g}(\mathrm{x})=\mathrm{a}+\mathrm{bx}$ with

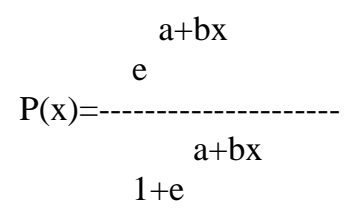

where $\mathrm{P}(\mathrm{x})$ denotes the conditional probability that $\mathrm{Y}$ occurs, conditional that it did not occur. In other words, $\mathrm{P}(\mathrm{x})=\mathrm{P}(\mathrm{Y}=1 / \mathrm{Y}=0)$ with $\mathrm{Y}$ denoting the outcome variable. 
The strict statistical assumptions set up by Palepu (1986), Karels and Prakash (1987), and Maddala (1991) are:

1. the equal probability distributed between the two groups of companies, and the efficiency of each model using different data;

2. further statistical implications related to the unequal sampling rates and,

3. the stability of discrete models overtime.

\section{Variables Selection}

Variables have been selected with the purpose of sketching an overall picture of a company's profile and according to the models used in the literature (see Appendix I; Maggina, 2008). Eleven variables have been included in each model. They have as follows:

$\mathrm{X}_{1} \quad$ Net Income/Total Assets (return on assets)

$\mathrm{X}_{2} \quad$ Cash/Current Liabilities (liquidity ratio)

$\mathrm{X}_{3} \quad$ Cash/Total Assets (liquidity ratio)

$\mathrm{X}_{4} \quad$ Quick Assets/Total Assets (quick ratio)

$\mathrm{X}_{5} \quad$ Current Assets/Sales (return of current assets on sales)

$\mathrm{X}_{6} \quad$ Net Worth/Total Debt (equity to debt ratio)

$\mathrm{X}_{7} \quad$ Receivables/Inventories (short-term financial ratio)

$\mathrm{X}_{8} \quad$ Working Capital/Total Assets (working capital percentage on total assets)

$\mathrm{X}_{9} \quad$ Total Debt/Total Assets (leverage ratio)

$\mathrm{X}_{10} \quad$ Net Income/Sales (return on sales ratio)

$\mathrm{X}_{11} \quad$ Sales/Working Capital (working capital turnover)

\section{EMPIRICAL ANALYSIS AND RESULTS}

\section{Problem (Troubled) Companies}

According to Mutchler (1985), auditors must first identify problem (troubled) companies and then decide whether to issue a going-concern opinion. Problem companies are defined as those that meet at least one of the following criteria (Chen and Church, 1992):

1. negative net worth,

2. negative cash flows,

3. negative operating income,

4. negative working capital,

5. negative net income,

6. negative retained earnings.

In this study, we define as problem (troubled) companies those that have negative net income for two consecutive years. They are 46 companies. They are composed of 18 companies with strictly unqualified reports and 20 companies with tax contingent liabilities. Two companies have qualified reports, six companies have goingconcern opinions, one company has matters of emphasis, and nineteen companies have tax contingent liabilities. Other reasons for notes are overdue liabilities, financial restructuring, negative net equity and, inventory valuation.

In a consideration of means of each variable used in the analysis, results are more illustrative of the differences between groups of companies. As close as we go a concern appears with variables $\mathrm{X}_{7}, \mathrm{X}_{2}, \mathrm{X}_{11}, \mathrm{X}_{6}$ and $\mathrm{X}_{10}$. Obviously, this is an evidence that Receivables/Inventories, Cash/Current Liabilities, Sales/Working Capital, Net Worth/Total Debt and, Net Income/Sales are the most crucial variables in the discriminating process as well as the predictive ability of models employed in this study (Descriptive statistics are available upon request). 
A non-parametric method and a suitable one for ordinal data specifies the most significant variables at 5\% level of significance. Kolmogorov-Smirnov is an appropriate statistic to test normality. It is of high importance to test normality because outliers may have a big influence. Prior studies have shown that non-normally distributed financial ratios are characterized with the presence of outliers. Most outliers are presented for variables $\mathrm{X}_{7}$ (Receivables/Inventories) and $\mathrm{X}_{11}$ (Sales/Working Capital) for problem companies and $\mathrm{X}_{7}$ (Working Capital/Total Assets), $\mathrm{X}_{11}$ (Sales/Working Capital), $\mathrm{X}_{6}$ (Net Worth/Total Debt) and $\mathrm{X}_{2}$ (Cash/Current Liabilities) for non-problem companies.

All variables in non-problem companies are non-normally distributed. The same happens with problem companies except for variable $\mathrm{X}_{4}$ (Quick Assets/Total Assets). Normality statistics are available upon request.

The choice of the best fitting model is stressed through a discussion of all empirical findings drawn from a test of discriminant and logit analysis. Coefficients for each model and for each variable are given below:

Table 1: Regression Coefficients (All Data)

\begin{tabular}{|c|c|c|}
\hline & Panel A: All Data & Logistic Coefficients \\
\hline (Factor) & Discriminant Coefficients & -37.171 \\
\hline$X_{1}$ & -0.077 & 0.032 \\
\hline$X_{2}$ & -0.042 & 2.985 \\
\hline$X_{3}$ & 0.051 & 0.045 \\
\hline$X_{4}$ & -0.154 & -0.028 \\
\hline$X_{5}$ & 0.037 & -0.176 \\
\hline$X_{6}$ & -0.010 & 0.000 \\
\hline$X_{7}$ & 0.050 & -1.354 \\
\hline$X_{8}$ & 0.712 & -1.002 \\
\hline$X_{9}$ & 0.068 & -1.082 \\
\hline$X_{10}$ & 0.693 & -0.964 \\
\hline$X_{11}$ & 0.158 & $X^{2}=207.111$ \\
\hline & Eigenvalue $=0.182$ & Significance $=0.000$ \\
\hline & Correlation $=0.393$ & Wald Test $=159.794$ \\
\end{tabular}

\begin{tabular}{|c|c|c|}
\hline & Panel B: Outliers Excluded & Logistic Coefficients \\
\hline (Factor) & Discriminant Coefficients & -35.005 \\
\hline$X_{1}$ & -0.210 & 0.055 \\
\hline$X_{2}$ & -0.144 & 1.313 \\
\hline$X_{3}$ & 0.237 & 0.519 \\
\hline$X_{4}$ & -0.260 & 0.810 \\
\hline$X_{5}$ & -0.141 & -0.020 \\
\hline$X_{6}$ & -0.100 & -0.113 \\
\hline$X_{7}$ & 0.270 & -1.108 \\
\hline$X_{8}$ & 0.738 & -0.208 \\
\hline$X_{9}$ & 0.013 & -1.544 \\
\hline$X_{10}$ & 0.635 & -0.048 \\
\hline & 0.376 & $X^{2}=157.056$ \\
& Eigenvalue $=0.252$ & Significance $=0.000$ \\
\hline & Correlation $=0.449$ & Wald Test $=137.718$ \\
\end{tabular}


Wilks' Lamda which is one of the various statistics available is used to test the significance of the discriminant function as a whole. As shown in Table 1 the significant lamda means that the null hypothesis (that the two groups have the same mean discriminant function scores) can be rejected and conclude that the model is discriminating. In discriminant analysis, almost all variables contribute marginally (see Table 1). In contrast, variables $\mathrm{X}_{1}$ (Net Income/Total Assets), $\mathrm{X}_{3}$ (Cash/ Total Assets), $\mathrm{X}_{8}$ (Working Capital/Total Assets), $\mathrm{X}_{9}$ (Total Debt/Total Assets) and $\mathrm{X}_{10}$ (Net Income/Sales) are the most differentiating variables in case a logit model.

Furthermore, the low eigenvalue means that each variable alone cannot sufficiently explain the model. In discriminant analysis the significance of the test is a strong evidence which leads to the selection of the best statistical technique.

Once the values of the discriminant coefficients are estimated, it is possible to calculate discriminant scores for each observation in the sample, or any firm, and to assign the observations to one of the groups based on this score. The essence of this procedure is to compare the profile of an individual firm with that of the alternative groupings. In this manner, the firm is assigned to the group it is most closely resembles.

As far as the correct classification, results offered in next Table 2 justify the preference of logit against discriminant analysis. Problem companies are more correctly classified using logit.

Table 2: Classification Table For GROUP (Percent Correct-Overall Index)

\begin{tabular}{|c|c|c|c|c|}
\hline \multirow{4}{*}{ Panel A: All Data } & \multicolumn{2}{|c|}{ Discriminant Analysis } & \multicolumn{2}{|c|}{ Logit Model } \\
\hline & $332(85.6)$ & $56(14.4)$ & 377 & $11(97.2)$ \\
\hline & $39(45.3)$ & $47(54.7)$ & 36 & $50(58.1)$ \\
\hline & \multicolumn{2}{|c|}{$80.00 \%$} & \multicolumn{2}{|c|}{$90.10 \%$} \\
\hline \multirow{3}{*}{ Panel B: Outliers Excluded } & $276(883)$ & $39(117)$ & 308 & $7(978)$ \\
\hline & $25(42.6)$ & $36(57.4)$ & 26 & $35(57.4)$ \\
\hline & \multicolumn{2}{|c|}{$83.00 \%$} & \multicolumn{2}{|c|}{$91.20 \%$} \\
\hline
\end{tabular}

This finding is very close to other business paradigms (i.e. bankruptcies, mergers and acquisitions, etc.).It is worth noting that percentage of correctly classified companies is much lower in other fields of business research such as acquired versus non-acquired companies when percentage ranges around 76\% and 73\% in discriminant and logit analysis, respectively.

Based on the above empirical findings, it is suggested that the prediction model is an accurate forecast of problem companies.

\section{GOING-CONCERN OPINIONS}

Going-concern opinions can be predicted successfully using financial variables. According to Carmichael(1972) elements pointing to going-concern problems have as follows: A) Financial problems (liquidity deficiency, equity deficiency, debt default, funds shortage), and B) operating problems (continued operating losses, prospective revenues doubtful, ability to operate is jeopardized, poor control over operations).

In this study there are nine companies with going-concern opinions. Almost all going-concern opinions have been issued by SOL (the former Sworn-in-Auditors, the former state-controlled Board) and no company with going-concern opinion reports the Board of Directors' size and composition. When considering the means of each variable used in the analysis, we see that results are more illustrative of the differences between groups of companies. Differences between the two groups of companies, that is, companies with and without going-concern opinions are more apparent for variables $\mathrm{X}_{7}$ (Receivables/Inventories), $\mathrm{X}_{2}$ (Cash/Current Liabilities), $\mathrm{X}_{11}$ (Sales/Working Capital), $\mathrm{X}_{6}$ (Net Worth/Total Debt), and $\mathrm{X}_{10}$ (Net Income/Sales). Descriptive statistics are available upon request. 
In a consideration of normality using Kolmogorov-Smirnov z-statistic it is shown that except variable $\mathrm{X}_{1}$ (Net Income/Total Assets) all other variables for companies with going-concern opinions are almost normally distributed in case of either all data or with outliers omitted .In contrast, all variables are not normally distributed in case of companies without going-concern opinions. It is worth noting that almost all variables of companies with going-concern opinions do not have outliers (except variable $\mathrm{X}_{1}$ (Net Income/Total Assets) with four outliers). In adverse, companies without going-concern opinions exhibit a great number of outliers in case of variables $\mathrm{X}_{11}$ (Sales/Working Capital), $\mathrm{X}_{7}$ (Receivables /Inventories), $\mathrm{X}_{2}$ (Cash/Current Liabilities), and $\mathrm{X}_{6}$ (Net Worth/Total Debt. Normality statistics are available upon request.

Coefficients for each model and for each variable indicate that the most discriminating variables are $\mathrm{X}_{8}$ (Working Capital/Total Assets) and $\mathrm{X}_{4}$ (Quick Ratio) when using all data while all variables contribute marginally when outliers are omitted in case of the discriminant analysis. As expected a great number of variables contribute to the classification of the two groups of companies when logit is employed. These variables are the following: $\mathrm{X}_{5}$ (Current Assets/Sales), $\mathrm{X}_{3}$ (Cash/ Total Assets), $\mathrm{X}_{1}$ (Net Income/Total Assets), $\mathrm{X}_{6}$ (Net Worth/Total Debt), and $\mathrm{X}_{10}$ (Net Income/Sales). Wilk's lamda indicated that the model is rather discriminating.

Table 3: Regression Coefficients (All Data)

\begin{tabular}{|c|c|c|}
\hline & Panel A: All Data & Logistic Coefficients \\
\hline (Factor) & Discriminant Coefficients & -3.539 \\
\hline$X_{1}$ & -0.359 & -0.883 \\
\hline$X_{2}$ & -0.013 & 19.179 \\
\hline$X_{3}$ & -0.110 & 0.871 \\
\hline$X_{4}$ & -1.254 & -14.232 \\
\hline$X_{5}$ & -0.001 & -2.745 \\
\hline$X_{6}$ & 0.000 & 0.000 \\
\hline$X_{7}$ & 0.000 & -0.682 \\
\hline$X_{8}$ & 2.898 & -0.013 \\
\hline$X_{9}$ & -0.119 & -2.463 \\
\hline$X_{11}$ & 0.742 & 0.002 \\
\hline & 0.000 & $X^{2}=79.327$ \\
\hline & Eigenvalue $=0.409$ & Significance $=0.000$ \\
Wald Test $=180.899$
\end{tabular}




\begin{tabular}{|c|c|c|}
\hline & Panel B: Outliers Excluded & Logistic Coefficients \\
\hline (Factor) & Discriminant Coefficients & -4.920 \\
\hline$X_{1}$ & -0.269 & -0.981 \\
\hline$X_{2}$ & -0.421 & 32.083 \\
\hline$X_{3}$ & -0.136 & -137 \\
\hline$X_{4}$ & -0.317 & -21.697 \\
\hline$X_{5}$ & 0.160 & -5.265 \\
\hline$X_{6}$ & 0.215 & -0.084 \\
\hline$X_{7}$ & 0.159 & -0.514 \\
\hline$X_{8}$ & 1.141 & -0.011 \\
\hline$X_{9}$ & -0.047 & -2.682 \\
\hline$X_{10}$ & 0.590 & 0.125 \\
\hline & 0.135 & $X^{2}=71.990$ \\
\hline & Eigenvalue $=0.451$ & Significance $=0.000$ \\
Wald Test $=139.856$ \\
\end{tabular}

As far as the correct classification is concerned, results reported in the next Table 4 justify the preference of logit against discriminant analysis but with discriminant analysis very close to logit. Going-concern opinions can be predicted with a very high rate either with discriminant analysis or logit.

Table 4: Classification Table For GROUP (Percent Correct-Overall Index)

\begin{tabular}{|c|c|c|c|c|}
\hline \multirow{4}{*}{ Panel A: All Data } & \multicolumn{2}{|c|}{ Discriminant Analysis } & \multicolumn{2}{|c|}{ Logit Model } \\
\hline & $453(99.3)$ & $3(0.7)$ & 454 & $2(99.6)$ \\
\hline & $11(61.1)$ & $7(38.9)$ & 9 & $9(50.0)$ \\
\hline & \multicolumn{2}{|c|}{$97.00 \%$} & \multicolumn{2}{|c|}{$97.70 \%$} \\
\hline \multirow{4}{*}{ Panel B: Outliers Excluded } & \multicolumn{2}{|c|}{ Discriminant Analysis } & \multicolumn{2}{|c|}{ Logit Model } \\
\hline & $362(98.9)$ & $4(1.1)$ & 365 & $1(99.7)$ \\
\hline & $8(61.5)$ & $5(38.5)$ & 4 & $9(69.2)$ \\
\hline & \multicolumn{2}{|c|}{$\frac{1}{96.80 \%}$} & \multicolumn{2}{|c|}{$98.70 \%$} \\
\hline
\end{tabular}

This finding is very higher than other business paradigms (i.e. bankruptcies, mergers and acquisitions, etc.). Based on the above empirical findings, it is suggested that the prediction model is an accurate forecast of goingconcern opinions.

\section{TAX CONTINGENT LIABILITIES}

It should be noted that only $27 \%$ of firms make any disclosure of contingent tax liabilities and only $30 \%$ of firms that do disclose a tax contingency provide the detailed information required by SFAS No. 5 (Accounting for Contingencies). According to Gleason et al. (2002) firms operating in litigious industries are more likely to disclose contingent tax liabilities, consistent with Skinner's (1994) conclusion that disclosure reduces the cost of potential litigation. In an IFRS framework using a sample of 80 German firms it was noted that deferred taxes comprise the most frequent adjustment item, reported in $95 \%$ of the observations. Deferred taxes arise because IFRS eliminates tax-book conformity, which potentially affects every company (Hung and Subramanyam, 2007).

In this study there are ninety eight companies with tax contingent liabilities and one hundred seventy seven companies without tax contingent liabilities. The differences of means between the two groups of companies are focused on the following variables: $\mathrm{X}_{7}$ (Receivables/ Inventories), $\mathrm{X}_{11}$ (Sales/Working Capital), and $\mathrm{X}_{2}$ (Cash/Current Liabilities). When outliers are excluded the differences are very moderate. In both groups of companies outliers are presented in case of variables $\mathrm{X}_{11}$ (Sales/Working Capital), $\mathrm{X}_{7}$ (Receivables/Inventories), and $\mathrm{X}_{2}$ (Cash/ Current 
Liabilities). Descriptive statistics are available upon request. All variables are non-normally distributed. Normality statistics are available upon request.

The choice of the best fitting model is stressed through a discussion of all empirical findings drawn from a test of discriminant and logit. Regression coefficients for each model and for each variable indicate that all variables contribute marginally in both discriminant analysis and the logit specification. The point is that results are not statistically significant as in the other regressions made about problem companies and going-concern opinions.

Table 5: Regression Coefficients (All Data)

\begin{tabular}{|c|c|c|}
\hline & Panel A: All Data & Logistic Coefficients \\
\hline (Factor) & Discriminant Coefficients & 1.321 \\
\hline$X_{1}$ & 0.518 & -3.018 \\
\hline$X_{2}$ & 0.565 & 0.553 \\
\hline$X_{3}$ & -0.277 & 1.180 \\
\hline$X_{4}$ & 0.246 & -0.017 \\
\hline$X_{5}$ & 0.367 & 0.001 \\
\hline$X_{6}$ & -0.127 & 0.230 \\
\hline$X_{7}$ & 0.452 & 0.593 \\
\hline$X_{8}$ & -0.073 & -0.242 \\
\hline$X_{10}$ & 0.410 & 0.003 \\
\hline$X_{11}$ & -0.518 & $X^{2}=24.647$ \\
& 0.209 & Significance $=0.010$ \\
& Eigenvalue $=0.036$ & Test $=28.749$ \\
\end{tabular}

\begin{tabular}{|c|c|c|}
\hline & Panel B: Outliers Excluded & Logistic Coefficients \\
\hline (Factor) & Discriminant Coefficients & 0.1444 \\
\hline$X_{1}$ & 0.714 & -1.984 \\
\hline$X_{2}$ & 0.545 & 0.358 \\
\hline$X_{3}$ & -0.447 & 0.965 \\
\hline$X_{4}$ & 0.240 & -0.139 \\
\hline$X_{5}$ & 0.668 & -0.034 \\
\hline$X_{6}$ & -0.588 & -0.087 \\
\hline$X_{7}$ & -0.389 & 0.370 \\
\hline$X_{8}$ & -0.285 & -0.246 \\
\hline$X_{9}$ & 0.444 & -0.008 \\
\hline$X_{11}$ & -0.361 & $X^{2}=13.738$ \\
& -0.032 & Significance $=0.248$ \\
\hline & Eigenvalue $=0.030$ & Wald Test $=26.830$ \\
\hline
\end{tabular}

As far as the correct classification, results reported in next Table 6 justify the almost equivalent preference of discriminant analysis or logit. It is worth noting that the rate of correct classification is moderate, very lower than the rate in the classification of problem companies or the rate for companies with going-concern opinions and lower than other business paradigms such as acquired companies, bankrupt companies, etc. 
Table 6: Classification Table For GROUP (Percent Correct-Overall Index)

\begin{tabular}{|c|c|c|c|c|}
\hline \multirow{4}{*}{ Panel A: All Data } & \multicolumn{2}{|c|}{ Discriminant Analysis } & \multicolumn{2}{|c|}{ Logit Model } \\
\hline & $207(69.9)$ & $89(30.1)$ & 288 & $8(97.3)$ \\
\hline & $101(56.7)$ & $77(43.3)$ & 156 & $22(12.4)$ \\
\hline & \multicolumn{2}{|c|}{$59.90 \%$} & \multicolumn{2}{|c|}{$65.40 \%$} \\
\hline \multirow{4}{*}{ Panel B: Outliers Excluded } & \multicolumn{2}{|c|}{ Discriminant Analysis } & \multicolumn{2}{|c|}{ Logit Model } \\
\hline & $139(57.9)$ & $101(42.1)$ & 236 & $4(98.3)$ \\
\hline & $68(49.3)$ & $70(50.7)$ & 124 & $14(10.1)$ \\
\hline & \multicolumn{2}{|c|}{$55.30 \%$} & \multicolumn{2}{|c|}{$66.10 \%$} \\
\hline
\end{tabular}

\section{CONCLUSIONS AND SUGGESTIONS FOR FURTHER FUTURE RESEARCH}

The prediction accuracy that was assessed in this study indicates that the models tested can operate as a decision support system with an effective aid to the auditors in their effort to form their judgments. Most noticeable is the situation with going-concern opinions whereas over $96.0 \%$ accuracy was achieved. From a statistical point of view logit performed better than discriminant analysis with marginal differences in going-concern opinions but with great differences in problem companies classification and tax contingent liabilities. This study is subject to limitations drawn from the fact that only publicly traded companies have been employed for a statistical analysis. The employment of privately held companies would make results capable of generalizing the figures.

A great role in audit reports has been played by Audit Committees (ACs) internationally through the level of negotiation and the level of discussion in an auditor/client interaction. In Greece the institution of ACs rated as $7 \%$ in 2005 and $17.36 \%$ in 2007 over the total number of ASE listed companies opens a new way for future research about the "black box". Concerns about the proposition that auditors act in the interest of managers that hire them rather than in the interest of investors in the framework of the adoption of IFRS is another area for research. In Greece it is argued by ex-top execs that qualified audit reports have been eliminated after a long experience of substantial notes of auditors in audit reports. On the other hand, the involvement of auditing firms at least in training programs to ASE listed companies in the transition to IFRS and the different accounting framework in which listed companies have been called to operate have left a "flight from audit quality" still for further investigation. Another venue for research is the investigation of the effect of the wages and salary rates on hiring policies and decisions on engaging the auditing firms by the ASE listed companies. A whole new area of further research would be to examine the behavior of internal auditors as it is compared with that of the external auditors and also the relationship and the effect of the internal control reports and the regular (external) auditing reports. It would also be of interest to further investigate the effect of the transparency of auditing fees on auditing firms' competition.

\section{AUTHOR INFORMATION}

Anastasia G. Maggina is a Ph.D. holder in Accounting graduated at the Aristotle University of Thessaloniki and is currently a business consultant and researcher. She has taught at Greek Universities and American Universities in Greece. She has worked at the Center of Planning and Economic Research (Ministry of National Economy) and as a senior Consultant. She has published in many scholarly Journals and in several Greek newspapers. She has published several books and monographs. She has provided professional services in various Committees and AAA Meetings as well as in various Journals as a reviewer and as member of the Editorial Boards.

Professor Angelos A. Tsaklanganos is a Professor of Accounting at the University of Nicosia, Cyprus and an Emeritus Professor of the Aristotle University of Thessaloniki, Greece. He has a Ph.D. and MBA from New York University, Stern School of Business and has taught at N.Y.U./Stern, Baruch College of the City University of New York, Rutges University, Temple University, Columbia University and Lavern University. His articles appear in many scholarly journals. He has written over 20 books in Accounting and Business Administration (in Greek) and was a Consultant for the Ministry of National Economy, the Telephon Co, the Power Co and other businesses. He served as President of the Productivity Center and Board Member in many public and private enterprises. 


\section{REFERENCES}

1. Altman, E. (1974), Evaluation of a Company as a Going-Concern, The Journal of Accountancy (December), pp. 50-57.

2. $\quad$------(1982), Accounting Implications of Failure Prediction Models, Journal of Accounting, Auditing and Finance, pp. 4-19

3. Bell, T. and R. Talbor (1991), Empirical Analysis of Audit Uncertainty Qualifications, Journal of Accounting Research, 29, pp. 350-370

4. Bartov, E, Gul, F.A. and J.S.L. Tsui (2001), Discretionary-accruals Models and Audit Qualifications, Journal of Accounting and Economics, 30, pp. 421-452

5. Caramanis, C. and C. Spathis (2006), Auditee and Audit Firm Characteristics as Determinants of Audit Qualifications: Evidence from the Athens Stock Exchange, Managerial Auditing Journal, 21, 9, pp. 905-20

6. Carmichael, D.R. (1972), The Auditor's Reporting Obligation, Auditing Research Monograph No. 1 (New York: AICPA).

7. Chen, K. and B. Church (1992), Default on Debt Obligations and the Issuance of Going-Concern Opinions, Auditing: A Journal of Practice and Theory, Fall, pp. 30-49

8. Choi S.K. and D.C. Jeter (1992), The Effect of Qualified Audit Opinion on Earnings Response Coefficients, Journal of Accounting and Economics, 15, 2/3, pp. 229-247

9. Cormier, D. M. Magnan and B. Morard (1995), The Auditors' Consideration of the Going-Concern Assumption: A Diagnostic Model, Journal of Accounting, Auditing and Finance, Spring, pp. 201-222

10. Deakin, E.B. (1977), Business Failure Prediction: An Empirical Analysis in E.I. Altman and A.W. Sametz, Eds. Financial Crises: Institutions and Markets in a Fragile Environment (John Wiley \& Sons), pp. 72-88

11. Dodd, P., Dopuch, N., R. Holthausen and R. Leftwich (1984), Qualified Audit Opinions and Stock Prices: Information Content, Announcement Dates, and Concurrent Disclosures, Journal of Accounting and Economics, (April), pp. 3-38

12. Dopuch, N., R. Holthausen and R. Leftwich (1987), Predicting Audit Qualifications with Financial and Market Variables, The Accounting Review, 62, 3, pp. 431-454

13. Elliott, J. (1982), "Subject to" Audit Opinions and Abnormal Security Returns: Outcomes and Ambiguities, Journal of Accounting Research, (Autumn), pp. 617-638

14. Gaganis, C., F. Pasiouras and M. Doumpos (2007), Probabilistic Neural Networks for the Identification of Qualified Audit Reports, Expert Systems with Applications, 32, 1, pp. 114-124

15. Gleason, C. A. and L. F. Mills (2002), Materiality and Contingent Tax Liability Reporting, The Accounting Review, 77, 2, pp. 317-342

16. Goodman B., D.N. Braunstein and G.W. Gregory (1995), Explaining Auditors' Going-Concern Decisions, Journal of Applied Business Research,11,3,pp. 82-95

17. Grant Thorton (2006),Study on the Impact of IFRS Application on Greek Listed Companies In the Athens Stock Exchange(ASE), June, www.grant-thorton.gr (in Greek)

18. Hirst, D.E. (1994), Auditor Sensitivity to Earnings Management, Contemporary Accounting Research, 11, pp. 405-422

19. Hopewood, W., J. McKeow and J. Mutchler (1989),A Test of the Incremental Power of Opinions Qualified for Consistency and Uncertainty, The Accounting Review, LXIV, 1, pp. 28-47

20. Ireland, J.C. (2003), An Empirical Investigation of Determinants of Audit Reports in the UK, Journal of Business Finance and Accounting, 30, 7, pp. 975-1015

21. Karels, G. and A. Prakash (1987), Multivariate Normality and Forecasting of Business Bankruptcy, Journal of Business Finance and Accounting, 14, 4, pp. 573-593

22. Keasey K., R. Watson and P. Wynarzcyk (1988), The Small Company Audit Qualification: A Preliminary Investigation, Accounting and Business Research, 18, pp. 323-333

23. Kida, T. (1980), An Investigation Into Auditor's Continuity and Related Qualification Judgments, Journal of Accounting Research, Autumn, pp. 506-523

24. Kleinman, G. and A. Anandarajan (1999), The Usefulness of Off-Balance-sheet Variables as Predictors of Auditors' Going-Concern Opinions: An Empirical Analysis, Managerial Auditing Journal, 14, 6, pp. 273285

25. Koh, H.C. (1991), Model Predictions and Auditor Assessments of Going-Concern Status, Accounting and Business Research, 21, 4, pp. 331-338 
26. Koh, H.C. and L.N. Killough (1990), The Use of Multiple Discriminant Analysis in the Assessment of the Going-Concern Status of an Audit Client, Journal of Business Finance and Accounting, 17, 2, pp. 179-191

27. Laitinen, E.K. and T. Laitinen (1998), Qualified Audit Reports in Finland: Evidence from Large Companies, European Accounting Review, 7, 4, pp. 639-653

28. Louder M.L., I.K. Khurana, R. Sawyers, C. Cordery, C. Johnson, J. Lowe and R. Wunderle (1992), The Information Content of Audit Qualifications, Auditing: A Journal of Practice and Theory, 11, pp. 69-82

29. Maddala, G.S. (1991), A Perspective on the Use of Limited-Dependent and Qualitative Variables:Models in Accounting Research, The Accounting Review, 66, 4, pp. 788-807

30. Maggina, A. (2008), On the Distributional Properties of Financial Ratios in Annual Reports of Greek Listed Companies, International Journal of Managerial and Financial Accounting, 1, 2, pp. 166-183

31. Martens,D., L. Bruynseels, B. Baesens, M. Wiltekens and J. Vanthienen (2008),Predicting Going-Concern Opinion with Data Mining, Decision Support Systems, 45, 4, pp. 765-777

32. McKee, T.E. (1976), Discriminant Prediction of Going-Concern Status: A Model for Auditors, Selected Papers of the AAA Annual Meeting

33. McKeown, J.C., J.E. Mutchler and W. Hopewood (1991), Towards an Explanation of Auditor Failure to Modify the Audit Opinions of Bankrupt Companies, Auditing:A Journal of Practice and Theory, 10, Supplement, pp. 1-13

34. Menon, K. and K.B. Schwartz (1987), An Empirical Investigation of Audit Qualification Decisions in the Presence of Going-Concern Uncertainties, Contemporary Accounting Research (Spring), pp. 302-315

35. Mutchler, J. (1985), A Multivariate Analysis of the Auditor's Going-Concern Opinion Decision, Journal of Accounting Research, Autumn, pp. 668-682

36. - Auditing: A Journal of Practice and Theory, Fall, pp. 148-163

37. Mutchler, J., W. Hopewood and J. McKeown (1997), The Influence of Contrary Information and Mitigating Factors on Audit Opinion Decisions on Bankrupt Companies, Journal of Accounting Research, 35, pp. 295310

38. Palepu, K.G. (1986), Predicting Take-Over Targets: A Methodological and Empirical Analysis, Journal of Accounting and Economics, pp. 3-35

39. Skinner, D.J. (1994), Why Firms Voluntarily Disclose Bad News, Journal of Accounting Research, Spring, pp. 38-60

40. Spathis, C. (2002), Detecting False Financial Statements Using Published Data: Some Evidence from Greece, Managerial Auditing Journal, 17, 4, pp. 179-191

41. -------(2003), Audit Qualification, Firm Litigation and Financial Information: An Empirical Analysis in Greece, The International Journal of Auditing, 7, pp. 71-5

42. Summers S.L. and J.T. Sweney (1998), Fraudently Misstated Financial Statements and Insider Trading: An Empirical Analysis, The Accounting Review, 73, 1, pp. 131-146

43. Sundgren, S. (1998), Auditor Choices and Auditor Reporting Practices: Evidence from Finish Small Firms, European Accounting Review, 7, 3, pp. 441-465

\section{NOTES}

*There are at least three reasons for the very high percentage of unqualified audit reports:

1. the auditors may not be competent to identify risks and therefore do not qualify (competence)

2. auditors do not act independently so that their decision is influenced by other considerations such as the effect of qualification on (a)the future prosperity of the client's business or (b)their own business in terms of possible litigation and loss of audit (independence)

3. the annual reports are of high quality and simply do not need qualification.

Bavishi (1993) showed that none of the audit reports from large Finnish companies in his study ( 35 and 50 from the years 1987 and 1990) contained a qualification.

**The market's responsiveness to an earnings announcement is measured by the slope coefficient (ERC) in the regression of unexpected returns on unexpected earnings. 
Earnings persistence is measured by the extent to which the current earnings shock alters the market's expectation of future earnings.

***A firm was considered to have going-concern problems if it was likely that the firm would experience one or more of the following events within one year:

- $\quad$ enter receivership

- $\quad$ enter reorganization proceedings

- $\quad$ inability to meet interest payments

- $\quad$ experience its third consecutive year of substantial losses

- $\quad$ liquidate its assets

- $\quad$ experience its third consecutive year of significant deficits.

A "going-concern opinion" is a special type of the subject-to opinion which indicates that the auditor believes the financial statement results to be fairly presented "subject-to" the resolution of the going-concern uncertainties.

A "subject-to" opinion is issued when uncertainty exists about the outcome of a particular event; this includes the case where there are doubts about the continued existence of an entity. 